\title{
In Vitro antibacterial and antibiotic-potentiation activities of four edible plants against multidrug-resistant gram-negative species
}

\author{
Jaurès AK Noumedem ${ }^{1,2}$, Marius Mihasan², Jules R Kuiate ${ }^{1 *}$, Marius Stefan $^{2}$, Dumitru Cojocaru², \\ Jean P Dzoyem ${ }^{1}$ and Victor Kuete ${ }^{1 *}$
}

\begin{abstract}
Background: The present study was designed to investigate the antibacterial activities of the methanol extracts of four Cameroonian edible plants, locally used to treat microbial infections, and their synergistic effects with antibiotics against a panel of twenty nine Gram-negative bacteria including Multi-drug resistant (MDR) phenotypes expressing active efflux pumps.

Methods: The broth microdilution method was used to determine the minimum inhibitory concentrations (MICs) of the extracts [alone and in the presence of the efflux pumps inhibitor (EPI) Phenylalanine-Arginine $\beta$ -

Naphtylamide (PABN)], and those of antibiotics in association with the two of the most active ones, Piper nigrum and Telfairia occidentalis. The preliminary phytochemical screening of the extracts was conducted according to the standard phytochemical methods.

Results: Phytochemical analysis showed the presence of alkaloids and flavonoids in all studied extracts. Other chemical classes of secondary metabolites were selectively present in the extracts. The results of the MIC

determination indicated that the crude extracts from P. nigrum and $V$. amygdalina were able to inhibit the growth of all the twenty nine studied bacteria within a concentration range of 32 to $1024 \mu \mathrm{g} / \mathrm{mL}$. At a similar concentration range (32 to $1024 \mu \mathrm{g} / \mathrm{mL}$ ) the extract from $T$. occidentalis inhibited the growth of $93.1 \%$ of the tested microorganisms. At $\mathrm{MIC} / 2$ and $\mathrm{MIC} / 5$, synergistic effects were noted between the extracts from $P$. nigrum and $T$. occidentalis and seven of the tested antibiotics on more than $70 \%$ of the tested bacteria.

Conclusion: The overall results of the present study provide information for the possible use of the studied edible plants extracts in the control of bacterial infections including MDR phenotypes.
\end{abstract}

Keywords: Antibacterial activities, Edible plants, Gram-negative bacteria, Multidrug resistance, Efflux pumps

\section{Background}

Despite the impressive scientific progress in vaccination and chemotherapy, infectious diseases remain a serious health issue. Following the massive and inappropriate use of antibiotics, bacteria have developed various mechanism of resistance; consequently, infectious diseases remain one of the leading causes of morbidity worldwide [1]. Microbial infections constitute a major public health problem in developing countries [2] where the high cost

\footnotetext{
*Correspondence: jrkuiate@yahoo.fr; kuetevictor@yahoo.fr

${ }^{1}$ Department of Biochemistry, Faculty of Science, University of Dschang, Dschang, Cameroon

Full list of author information is available at the end of the article
}

of antibiotics makes them unaffordable to the majority of the population. Therefore, the discovery of new antimicrobial agents is still relevant nowadays. Among the bacterial resistance mechanisms, efflux of antibiotics plays an important role; In fact it is widely recognized that the expression of efflux pumps encoded by housekeeping genes in bacteria is largely responsible for the phenomenon of intrinsic antibiotic resistance [3]. Also, the shortcomings of the drugs available today and the scarcity of novel antibiotics propel the discovery of new chemotherapeutic agents from medicinal plants [4]. The medicinal properties of many phytochemicals have been demonstrated [5]. In addition, promising new concepts

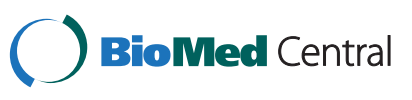


such as the efflux pump inhibitors [6,7], and synergy between antibiotics and phytochemicals are now been explored.

The present work was therefore designed to investigate the antibacterial potential of four Cameroonian edible plants used traditionally in the treatment of bacterial infections, namely the fruits of Piper nigrum L (Piperaceae), the leaves of Telfairia occidentalis Hook. F. (Cucurbitaceae) and Vernonia amygdalina Del. (Asteraceae) and the fruits of Syzygium aromaticum [L.] Merr \& Perry (Myrtaceae) against MDR bacteria expressing active efflux via the Resistance-Nodulation Cell Division (RND)-type pumps.

\section{Methods}

\section{Plant material and extraction}

The four edible plants used in this work were purchased from Dschang local market, West Region of Cameroon in June 2010. The collected plants material were the fruits of Piper nigrum, the fruits of Syzygium aromaticum, the leaves of Telfairia occidentalis and the leaves of Vernonia amygdalina. These plants were identified by M. Victor Nana of the National Herbarium (Yaounde-Cameroon) where all the voucher specimens were available under the reference numbers (see Table 1). The air dried and powdered sample $(1 \mathrm{~kg})$ from each plant was extracted with methanol $(\mathrm{MeOH})$ for $48 \mathrm{~h}$ at room temperature. The extracts were then filtered and concentrated under reduced pressure to give the crude extracts. All extracts were kept at $4^{\circ} \mathrm{C}$ until further investigations.

\section{Preliminary phytochemical investigations}

The major classes of secondary metabolites such as alkaloids, anthocyanins, anthraquinones, flavonoids, phenols, saponins, tannins, sterols and triterpenes were screened according to the common phytochemical methods described by Harbone [44].

\section{Bacterial strains and culture media}

The studied microorganisms included the reference (from the American Type Culture Collection) and clinical (Laboratory collection) strains of Providencia stuartii, Pseudomonas aeruginosa, K. pneumoniae, Escherichia coli, Enterobacter aerogenes and Enterobacter cloacae (See supporting information Additional file 1: Table S1 for their features). They were maintained in a Nutrient Broth at $4^{\circ} \mathrm{C}$ and activated on a fresh appropriate Mueller Hinton Agar plates $24 \mathrm{~h}$ prior to antimicrobial test. The Mueller Hinton Broth (MHB) was also used for all the antibacterial assays.

\section{Chemicals for antimicrobial assays}

Tetracycline (TET), cefepime (FEP), cloxacillin (CLX), streptomycine (STR), ciprofloxacine (CIP), norfloxacine
(NOR), chloramphenicol (CHL), cloxacillin (CLX), ampicillin (AMP), erythromycin (ERY), kanamycin (KAN) and streptomycin (STR) (Sigma-Aldrich, St Quentin Fallavier, France) were used as reference antibiotics. $p$-Iodonitrotetrazolium chloride (INT) and Phenylalanine Arginine $\beta$-naphthylamide (PA $\beta N)$ were used as microbial growth indicator and efflux pumps inhibitor (EPI) respectively.

\section{Bacterial susceptibility determination}

The MICs were determined using the rapid INT colorimetric assay $[45,46]$. Briefly, the test samples were first dissolved in DMSO/MHB. The solution obtained was then added to MHB, and serially diluted two fold (in a 96- wells microplate). One hundred microlitres $(100 \mu \mathrm{L})$ of inoculum $\left(1.5 \times 10^{6} \mathrm{CFU} / \mathrm{mL}\right)$ prepared in $\mathrm{MHB}$ was then added. The plates were covered with a sterile plate sealer, then agitated to mix the contents of the wells using a shaker and incubated at $37^{\circ} \mathrm{C}$ for $18 \mathrm{~h}$. The final concentration of DMSO was set at $2.5 \%$ (a concentration at which DMSO does not affect the microbial growth). Wells containing MHB, $100 \mu \mathrm{L}$ of inoculum and DMSO at a final concentration of $2.5 \%$ served as negative control (this internal control was systematically added). Chloramphenicol was used as reference antibiotic. The MICs of samples were detected after $18 \mathrm{~h}$ incubation at $37^{\circ} \mathrm{C}$, following addition of $40 \mu \mathrm{L}$ of a $0.2 \mathrm{mg} / \mathrm{mL}$ INT solution and incubation at $37^{\circ} \mathrm{C}$ for 30 minutes. Viable reduce the yellow dye to pink. MIC was defined as the lowest sample concentration that exhibited complete inhibition of microbial growth and then prevented this change [47].

Samples were tested alone and the best three extracts (those from the seeds of $P$. nigrum, T. occidentalis and $V$. amygdalina) were also tested in the presence of $\mathrm{PA} \beta \mathrm{N}$ at $30 \mathrm{mg} / \mathrm{L}$ final concentration. After a preliminary assay on one of the MDR bacteria, $P$. aeruginosa PA124 (See supporting information Additional file 1: Table S2), the two best extracts were those from $P$. nigrum and $T$. occidentalis. They were then selected and tested at $\mathrm{MIC} / 2$ and $\mathrm{MIC} / 5$ in association with antibiotics. Fractional inhibitory concentration (FIC) was calculated as the ratio of $\mathrm{MIC}_{\text {Antibiotic in combination }} / \mathrm{MIC}_{\text {Antibiotic alone }}$ and the results were discussed as follows: synergy $(\leq 0.5)$, indifferent $(0.5$ to 4$)$, or antagonism $(>4)[48,49]$. All assays were performed in triplicate.

\section{Results}

Phytochemical composition and antibacterial activity of the extracts

The results of the qualitative phytochemical analysis showed that each of the tested plant extract contains at least 3 classes of secondary metabolites (Table 2). The antibacterial activities of the extracts alone and 


\section{Table 1 Plants used in the present study and evidence of their bioactivities}

\begin{tabular}{|c|c|c|c|c|}
\hline $\begin{array}{l}\text { Plant (family); and } \\
\text { voucher number }\end{array}$ & Traditional uses & Parts used & $\begin{array}{l}\text { Bioactive or potentially bioactive } \\
\text { components }\end{array}$ & Bioactivities of extracts and/or compounds \\
\hline $\begin{array}{l}\text { Piper nigrum L. (Piperaceae); } \\
\text { 25818/SFRcam }\end{array}$ & $\begin{array}{l}\text { Cardiovascular diseases, intoxication, } \\
\text { inflammation, bacterial, fungal and } \\
\text { parasitic infections, respiratory } \\
\text { diseases, asthma [8] }\end{array}$ & $\begin{array}{l}\text { Seeds, bark, } \\
\text { leaves }\end{array}$ & $\begin{array}{l}\text { Piperine, pipene [9], piperamides, } \\
\text { piperamine [10], pellitorine [11] }\end{array}$ & $\begin{array}{l}\text { Anti-apoptotic [12,13], antibacterial [8,14], antidepressant [15] antifungal } \\
\text { [16], analgesic, anti-inflammatory [17], antidiarrhoeal [18], antimutagenic, } \\
\text { antioxidative, increase plasma [19], antipyretic [17], immuno-modulatory, } \\
\text { antispasmodic [20,21], asthma, obesity, sinus antispermatogenic, } \\
\text { antithyroid, antitumor Ciprofloxacin potentiator, transcription inhibitor, } \\
\text { insecticidal, hepatoprotective, increase pancreatic enzymes, Cytochrome } \\
\text { Inhibitor [8] }\end{array}$ \\
\hline $\begin{array}{l}\text { Syzygium aromaticum } \\
\text { (Myrtaceae) } 28524 / \mathrm{HNC}\end{array}$ & $\begin{array}{l}\text { Aphrodisiac, used to treat male } \\
\text { sexual disorders }[22,23] \text {, anti- } \\
\text { inflammatory, bacterial infections } \\
\text { [24], microbial infections }[25,26]\end{array}$ & fruits & $\begin{array}{l}\text { Eugenol (2-methoxy-4-(2-propenyl) } \\
\text { phenol), glycosides, flavonoids, } \\
\text { saponins and tannins [23], essential } \\
\text { oils }\end{array}$ & $\begin{array}{l}\text { Antipyretic, antispasmodic [27], anticarcinogenic [28], inhibition of 5-Lox } \\
\text { enzyme activity in human polymorphonuclear leukocytes cells [29], } \\
\text { antioxidant, protection against peroxynitrite-mediated tyrosine nitration } \\
\text { and lipid peroxidation [29], antifungal activity of essential oil [26] and } \\
\text { antimicrobial [25], antibacterial [30] }\end{array}$ \\
\hline $\begin{array}{l}\text { Telfairia occidentalis } \\
\text { (Curcubitaceae); 33423/HNC }\end{array}$ & $\begin{array}{l}\text { Microbial infections, cholesterolemia, } \\
\text { liver problems and impaired defense } \\
\text { immune systems [31] }\end{array}$ & $\begin{array}{l}\text { Leaves, } \\
\text { seeds, roots }\end{array}$ & Phenols, alkaloids and tannins [32] & $\begin{array}{l}\text { Antimicrobial, antioxidant and free radical-scavenger [32,33], } \\
\text { antiplasmodial, cure lactating properties, hypoglycemic and } \\
\text { antidiabetic [31] }\end{array}$ \\
\hline $\begin{array}{l}\text { Vernonia amygdalina Del. } \\
\text { (Asteraceae ); 31149/SRFK }\end{array}$ & $\begin{array}{l}\text { Microbial infections [34], hiccups, } \\
\text { kidney and stomach problems, } \\
\text { discomfort [35], stomach-ache and } \\
\text { gastrointestinal infections, malarial } \\
\text { fever, cough remedy [36], } \\
\text { anti-malarial, purgative, anti-parasitic, } \\
\text { eczema blood glucose levels control } \\
\text { [37], treatment of eczema [37] }\end{array}$ & $\begin{array}{l}\text { Leaves, } \\
\text { roots }\end{array}$ & $\begin{array}{l}\text { Flavonoids, saponins and alkaloids } \\
\text { [36], vernodalin, vernomygdin, } \\
\text { vernonioside B1 and vernoniol B1 } \\
\text { [38] }\end{array}$ & $\begin{array}{l}\text { Active anticancer [39], antimalarial and antiparasitic agents [40], } \\
\text { Hypoglycaemic [41], antimicrobial, antibacterial [35,40,42], antihelminthic, } \\
\text { anti-shitosomal, tumor inhibitor [38], hypolipidaemic and antioxidant } \\
\text { properties [43] }\end{array}$ \\
\hline
\end{tabular}


Table 2 Extraction yields, aspects and phytochemical composition of the plant extracts

\begin{tabular}{|c|c|c|c|c|c|c|c|c|c|c|c|c|}
\hline \multirow[t]{2}{*}{ Scientific names } & \multirow[t]{2}{*}{ Part used } & \multirow[t]{2}{*}{ Yield* (\%) } & \multirow[t]{2}{*}{ Physical aspect } & \multicolumn{8}{|c|}{ Secondary metabolites } & \multirow[b]{2}{*}{ Saponin } \\
\hline & & & & Alkaloids & Phenols & Tannins & Triterpenes & Steroids & Flavonoids & Anthraquinones & Anthocyanins & \\
\hline Piper nigrum & Fruits & 13.18 & Brown sticky paste & + & + & + & - & - & + & + & - & - \\
\hline Syzygium aromaticum & Fruits & 9.49 & Dark brown paste & + & - & - & - & - & + & - & - & - \\
\hline Telfairia occidentalis & Leaves & 11.58 & Brown sticky paste & + & + & + & - & - & + & - & + & - \\
\hline Vernonia amygdalina & Leaves & 7.16 & Green dark paste & + & + & + & - & + & + & - & - & + \\
\hline
\end{tabular}

(+): Present; (-): Absent; ${ }^{*}$ the yield was calculated as the ratio of the mass of the obtained methanol extract/mass of the plant powder. 
in some cases in combination with $\mathrm{PA} \beta \mathrm{N}$ on a panel of 29 Gram-negative bacteria are depicted in Table 3. It appears that extracts from $P$. nigrum and $V$. amygdalina inhibited the growth of all the twenty nine tested bacterial strains within a concentration range from 32 to $1024 \mu \mathrm{g} / \mathrm{mL}$. A good spectrum of antibacterial activity was also recorded with the extract of $T$. occidentalis, its inhibitory effects being observed against $27 / 29$ (93.1\%) of the tested microorganisms. The lowest MIC value $(32 \mu \mathrm{g} / \mathrm{mL})$ was obtained with the extract of $P$. nigrum on $P$. aeruginosa PA01.

Table 3 Minimal Inhibitory Concentration (MIC) in $\mu \mathrm{g} / \mathrm{mL}$ of methanol extracts from the studied plants and chloramphenicol

\begin{tabular}{|c|c|c|c|c|c|}
\hline \multirow[t]{2}{*}{ Bacteria strains } & \multicolumn{5}{|c|}{ Plant extracts and MICs $(\mu \mathrm{g} / \mathrm{mL})$} \\
\hline & Piper nigrum & Syzygium aromaticum & Telfairia occidentalis & Vernonia amygdalina & Chloramphenicol \\
\hline \multicolumn{6}{|l|}{ E. coli } \\
\hline ATCC8739 & 128 & 1024 & 512 & 512 & 4 \\
\hline ATCC10536 & 256 & - & 512 & 512 & 4 \\
\hline W3110 & 256 & 512 & 256 & 512 & 8 \\
\hline MC4100 & 256 & 1024 & 512 & 512 & 16 \\
\hline AG100A & $128(64)$ & - & $512(512)$ & $512(512)$ & $<2(<2)$ \\
\hline AG100Atet & $256(256)$ & - & $512(512)$ & $1024(1024)$ & $64(<2)$ \\
\hline AG102 & $512(128)$ & - & $1024(1024)$ & $256(256)$ & 64 \\
\hline AG100 & $256(32)$ & - & $512(512)$ & $512(32)$ & $8(<2)$ \\
\hline \multicolumn{6}{|l|}{ E. aerogenes } \\
\hline ATCC13048 & 512 & 1024 & 512 & 512 & 8 \\
\hline EA294 & 512 & - & 512 & 1024 & 16 \\
\hline CM64 & $512(256)$ & 1024 & $256(64)$ & $256(32)$ & $256(8)$ \\
\hline EA3 & $512(256)$ & - & 1024 (1024) & $512(512)$ & $256(128)$ \\
\hline EA298 & 256 (128) & - & $512(512)$ & $256(256)$ & $64(<2)$ \\
\hline EA27 & $512(256)$ & - & - & 1024 (1024) & $\geq 256(<2)$ \\
\hline EA289 & $512(256)$ & 1024 & $512(256)$ & $256(256)$ & $\geq 256$ (64) \\
\hline \multicolumn{6}{|l|}{ K. pneumoniae } \\
\hline ATCC11296 & 256 & 1024 & 1024 & 512 & 8 \\
\hline KP55 & $256(64)$ & - & $512(512)$ & $512(512)$ & $32(4)$ \\
\hline KP63 & $1024(256)$ & - & $256(256)$ & 1024 (1024) & $64(<2)$ \\
\hline K2 & 512 & - & - & 1024 & 32 \\
\hline K24 & 512 & - & 512 & 512 & 16 \\
\hline \multicolumn{6}{|l|}{ P. aeruginosa } \\
\hline PA01 & 32 & - & 512 & 512 & 16 \\
\hline PA124 & $256(128)$ & 512 & $512(512)$ & $1024(1024)$ & $32(<2)$ \\
\hline \multicolumn{6}{|l|}{ P. stuartii } \\
\hline ATCC29916 & 128 & - & 128 & 256 & 16 \\
\hline NAE16 & 512 & 1024 & 512 & 256 & 64 \\
\hline PS2636 & 256 & - & 512 & 512 & 32 \\
\hline PS299645 & 1024 (1024) & - & 1024 & 512 & 32 \\
\hline E. cloacae & & - & & & \\
\hline BM47 & 128 & - & 512 & 1024 & $\geq 256$ \\
\hline ECCI69 & 128 & - & 512 & 512 & $\geq 256$ \\
\hline BM67 & $128(32)$ & - & $512(16)$ & 1024 (1024) & $128(32)$ \\
\hline
\end{tabular}

(-) MIC > $1024 \mu \mathrm{g} / \mathrm{mL}$. 
Role of efflux pumps in the susceptibility of Gram-negative bacteria to the tested plant extracts

Fourteen of the studied MDR bacteria were also tested for their susceptibility to the most active plant extracts ( $P$. nigrum, $V$. amygdalina and $T$. occidentalis) in the presence $P A \beta N$ at $30 \mu \mathrm{g} / \mathrm{mL}$. When combined with extracts, PA $\beta N$ improved the activity (decrease of MIC values) of $P$. nigrum on almost all of the tested MDR strains [13/14 (92.9\%)]. The EPI also improved the activity of T. occidentalis against E. aerogenes CM64, EA 289 and E. cloacae BM67 as well as that of $V$. amygdalina against E. coli AG100 and E. aerogenes EA 289 (Table 3).

\section{Effect of the association of extracts with antibiotics}

A preliminary study (See supporting information; Additional file 1: Table S2) was performed against $P$. aeruginosa PA124 using the three most active plant extracts. The results permitted the selection of the extracts from $P$. nigrum and $T$. occidentalis with the appropriate sub-inhibitory concentrations of $\mathrm{MIC} / 2$ and $\mathrm{MIC} / 5$ for further studies. Therefore, the extracts from $P$. nigrum and $T$. occidentalis were combined with eleven antibiotics [TET, DOX, CIP, NOR, STR, KAN, CHL, ERY, FEP, CLX and AMP] separately to evaluate their possible synergistic effects. As results, synergistic effects were observed with the two extracts and most of the tested antibiotics except ß-lactams (AMP, FEP and CLX) (Tables 4 and 5). At MIC/2 and $\mathrm{MIC} / 5$ of the extract from $T$. occidentalis, synergistic effects were observed with 7 of the 11 antibiotics (TET, DOX, CIP, NFX, KAN, CHL, ERY) against the tested MDR bacteria (Table 5).

\section{Discussion}

\section{Antibacterial activities and chemical composition of the tested extracts}

Many secondary metabolites belonging to alkaloids, anthocyanins, anthraquinons, flavonoids, phenols, saponins, sterols, tannins and triterpenes were detected in the tested plant extracts. Several compounds from the investigated classes of phytochemicals were reported for their antibacterial activities [50,51], and their presence in the tested extracts could explain their antibacterial effects. The differences in bacterial susceptibility to the extracts may be either due to the differences in cell wall composition and/or genetic content of their plasmids [52] or to the differences in the composition and the mechanism of action of the bioactive compounds [53]. As shown in Table 3, the three most active plants ( $P$. nigrum, $T$. occidentalis and $V$. amygdalina) possess more classes of phytochemicals than the extract from S. aromaticum. Each of the three most active plant extracts contains at least four classes of secondary metabolites namely alkaloids, phenols, flavonoids and tannins. However, it should be noted that the activity does not depend on the number of classes of detected bioactive compounds, but mostly on their concentration. The inhibitory activity of $P$. nigrum was previously reported against some bacteria such as Staphylococcus aureus, Bacillus cereus, Streptococcus faecalis, Pseudomonas aeruginosa, Salmonella typhi and Escherichia coli [54], and the data reported in this study confirms the anti-infective potential of this plant. It has also been demonstrated that the acetone-ethanol extract of the leaves from $V$. amygdalina was weakly active against K. pneumoniae, E. coli, S. aureus, B. cereus, S. dysentriae and S. typhimurium [35] with MIC values ranged from $7.5 \mathrm{mg} / \mathrm{mL}$ to $25 \mathrm{mg} / \mathrm{mL}$ [42]. These activities are in accordance with the results obtained in the present work, but we observed higher antibacterial activity of this plant on all 29 bacteria including MDR phenotypes (with MIC values ranging between 256 and $1024 \mu \mathrm{g} / \mathrm{mL})$.

\section{Role of efflux pumps in the susceptibility of Gram-negative bacteria to the tested extracts and effects of the association of some extracts with antibiotics}

All the bacterial strains tested with a combination of plant extract and PA $\beta N$ were proven to possess multidrug resistance efflux pumps [55-59]. Tripartite efflux systems, mainly those clinically described such as AcrAB-TolC in Enterobacteriaceae or MexAB-OprM in P. aeruginosa play a central role in multidrug resistance of pathogenic Gramnegative bacteria $[55,56]$. PAßN, a potent inhibitor of the RND efflux systems is especially active on AcrAB-TolC and MexAB-OprM [57,58] and does not present any intrinsic effect on the bacteria at the concentration of $30 \mu \mathrm{g} / \mathrm{mL}$ used in this work [59]. In the presence of $\mathrm{PA} N$ at this concentration, significant increase of the activity of the extract from $P$. nigrum was noted against 13/14 of the tested MDR bacteria. This shows that at least one active compound from this plant, acting inside the bacteria cell could be the substrate of efflux pumps. From this observation, it can be suggested that the association of the extract of $P$. nigrum and efflux pump inhibitors could be helpful in the fight against infections due to MDR bacteria [5].

Moreover, we demonstrated in this study that the beneficial effect of the combination of two of the tested plant extracts namely those from $P$. nigrum and $T$. occidentalis, with the first line antibiotics could be achieved. Their synergistic effects with antibiotics were noted on more than $70 \%$ of the tested MDR bacteria (with seven antibiotics), also suggesting that some of their constituents can act as efflux pump inhibitor [49]. This hypothesis is emphasized by the fact that these extracts were more synergistic with antibiotics acting inside the bacteria cells. Besides, it has already been proved that the extract from $P$. nigrum can also act by 
Table 4 MIC of different antibiotics after the association of the extract of Piper nigrum at MIC/2, MIC/5 against eleven MDR bacteria strains

\begin{tabular}{|c|c|c|c|c|c|c|c|c|c|c|c|c|c|}
\hline \multirow[b]{2}{*}{ Antibiotics } & \multicolumn{13}{|c|}{ Bacterial strains, MIC $(\mu \mathrm{g} / \mathrm{mL})$ of antibiotics in the absence and presence of the extract } \\
\hline & Extract concentration & PA124 & AG100 & AG102 & AG100Atet & CM64 & EA3 & EA27 & EA289 & BM67 & KP55 & NEA16 & PBSS (\%) \\
\hline \multirow[t]{3}{*}{ TET } & 0 & 8 & 16 & 256 & 64 & 8 & 16 & 64 & 16 & 8 & $>256$ & 4 & \\
\hline & $\mathrm{MIC} / 2$ & $4(2)^{5}$ & $16(1)^{\prime}$ & $\leq 2(\geq 128)^{5}$ & $16(4)^{5}$ & $\leq 2(>4)^{5}$ & $4(4)^{5}$ & $16(4)^{5}$ & $16(1)^{\prime}$ & $8(1)^{\prime}$ & $>256$ & $\leq 2(>2)^{5}$ & 63.63 \\
\hline & $\mathrm{MIC} / 5$ & $4(2)^{5}$ & $16(1)^{\prime}$ & $\leq 2(\geq 128)^{5}$ & $16(4)^{5}$ & $\leq 2(>4)^{5}$ & $4(4)^{5}$ & $8(8)^{5}$ & $16(1)^{\prime}$ & $8(1)^{\prime}$ & $>256$ & $\leq 2(>2)^{5}$ & 63.63 \\
\hline \multirow[t]{3}{*}{ DOX } & 0 & 16 & 8 & 32 & 32 & 32 & 32 & 32 & 32 & 8 & 32 & 64 & na \\
\hline & $\mathrm{MIC} / 2$ & $8(2)^{5}$ & $\leq 2(>4)^{5}$ & $\leq 2(>16)^{5}$ & $\leq 2(>16)^{5}$ & $\leq 2(>16)^{5}$ & $4(8)^{5}$ & $8(4)^{5}$ & $32(1)^{1}$ & $\leq 2(>4)^{5}$ & $32(1)^{\prime}$ & $4(16)^{5}$ & 81.81 \\
\hline & $\mathrm{MIC} / 5$ & $8(2)^{5}$ & $\leq 2(>4)^{5}$ & $\leq 2(>16)^{5}$ & $\leq 2(>16)^{5}$ & $4(8)^{5}$ & $\leq 2(>16)^{5}$ & $8(4)^{5}$ & $16(1)^{\prime}$ & $\leq 2(>4)^{5}$ & $32(1)^{1}$ & $\leq 2(>32)^{5}$ & 81.81 \\
\hline \multirow[t]{3}{*}{ CIP } & 0 & 32 & 4 & 128 & 64 & 64 & 128 & $\leq 2$ & 8 & 128 & 64 & 128 & na \\
\hline & $\mathrm{MIC} / 2$ & $32(1)^{1}$ & $\leq 2(>2)^{5}$ & $16(8)^{5}$ & $4(16)^{5}$ & $8(8)^{5}$ & $64(2)^{5}$ & $\leq 2$ & $4(2)^{5}$ & $64(2)^{5}$ & $\leq 2(>32)^{5}$ & $64(2)^{5}$ & 90 \\
\hline & $\mathrm{MIC} / 5$ & $32(1)^{\prime}$ & $\leq 2(>2)^{5}$ & $64(2)^{5}$ & $16(4)^{5}$ & $4(16)^{5}$ & $64(2)^{5}$ & $\leq 2$ & $4(2)^{5}$ & $128(1)^{\prime}$ & $\leq 2(>32)^{5}$ & $128(1)^{\prime}$ & 70 \\
\hline \multirow[t]{3}{*}{ NFX } & 0 & 128 & 128 & 64 & 128 & $\leq 2$ & 128 & 32 & 64 & 128 & 128 & 256 & na \\
\hline & $\mathrm{MIC} / 2$ & $64(2)^{5}$ & $4(32)^{5}$ & $\leq 2(>32)^{5}$ & $16(8)^{5}$ & $\leq 2$ & $32(4)^{5}$ & $8(4)^{5}$ & $16(4)^{5}$ & $128(1)^{\prime}$ & $16(8)^{5}$ & $128(2)^{5}$ & 90 \\
\hline & $\mathrm{MIC} / 5$ & $128(1)^{\prime}$ & $\leq 2(>64)^{5}$ & $64(1)^{\prime}$ & $16(8)^{5}$ & $\leq 2$ & $32(4)^{5}$ & $16(2)^{5}$ & $16(4)^{5}$ & $128(1)^{\prime}$ & $16(8)^{5}$ & $128(2)^{5}$ & 80 \\
\hline \multirow[t]{3}{*}{ STR } & 0 & 256 & $\leq 2$ & 256 & 64 & 8 & 32 & 16 & 64 & $\leq 2$ & 4 & 64 & na \\
\hline & $\mathrm{MIC} / 2$ & $256(1)^{\prime}$ & $\leq 2$ & $64(4)^{5}$ & $\leq 2(>32)^{5}$ & $\leq 2(>4)^{5}$ & $\leq 2(>16)^{5}$ & $32(0.5)^{1}$ & $4(16)^{5}$ & $\leq 2$ & $\leq 2(>2)^{5}$ & $\leq 2(>32)^{5}$ & 77.78 \\
\hline & $\mathrm{MIC} / 5$ & $256(1)^{\prime}$ & $\leq 2$ & $64(4)^{5}$ & $\leq 2(>32)^{5}$ & $\leq 2(>4)^{5}$ & $4(8)^{5}$ & $16(1)^{\prime}$ & $4(16)^{5}$ & $\leq 2$ & $\leq 2(>2)^{5}$ & $\leq 2(>32)^{5}$ & 77.78 \\
\hline \multirow[t]{3}{*}{ KAN } & 0 & ND & 8 & 128 & 32 & $\leq 2$ & 16 & 16 & 32 & $\leq 2$ & 8 & $\leq 2$ & na \\
\hline & $\mathrm{MIC} / 2$ & ND & $\leq 2(>4)^{5}$ & $\leq 2(>64)^{5}$ & $16(2)^{5}$ & $\leq 2$ & $\leq 2(>8)^{5}$ & $4(4)^{5}$ & $4(8)^{5}$ & $\leq 2$ & $16(0.5)$ & $\leq 2$ & 75 \\
\hline & $\mathrm{MIC} / 5$ & ND & $\leq 2(>4)^{5}$ & $\leq 2(>64)^{5}$ & $4(8)^{5}$ & $\leq 2$ & $\leq 2(>8)^{5}$ & $4(4)^{5}$ & $4(8)^{5}$ & $\leq 2$ & $8(1)^{\prime}$ & $\leq 2$ & 75 \\
\hline \multirow[t]{3}{*}{$\mathrm{CHL}$} & 0 & 32 & 64 & $>256$ & 64 & 256 & 32 & $>256$ & $>256$ & 64 & 16 & 128 & na \\
\hline & $\mathrm{MIC} / 2$ & $16(2)^{5}$ & $4(16)^{5}$ & $16(>16)^{5}$ & $64(1)^{\prime}$ & $32(8)^{5}$ & $4(8)^{5}$ & $32(>8)^{5}$ & $>256$ & $32(2)^{5}$ & $8(2)^{5}$ & $8(16)^{5}$ & 81.81 \\
\hline & $\mathrm{MIC} / 5$ & $32(1)^{\prime}$ & $16(4)^{5}$ & $16(>16)^{5}$ & $64(1)^{\prime}$ & $128(2)^{5}$ & $4(8)^{5}$ & $64(>4)^{5}$ & $>256$ & $32(2)^{5}$ & 16 & $128(1)^{\prime}$ & 54.54 \\
\hline \multirow[t]{3}{*}{ ERY } & 0 & 128 & 32 & 256 & 128 & $>256$ & 256 & 64 & 256 & 256 & 256 & 256 & na \\
\hline & $\mathrm{MIC} / 2$ & $128(1)^{\prime}$ & $8(4)^{5}$ & $64(4)^{5}$ & $256(0.5)^{\prime}$ & $32(>8)^{5}$ & $64(4)^{5}$ & $32(2)^{5}$ & $256(1)^{\prime}$ & $64(4)^{5}$ & $16(16)^{5}$ & $64(4)^{5}$ & 72.72 \\
\hline & $\mathrm{MIC} / 5$ & $128(1)^{\prime}$ & $16(2)^{5}$ & $32(4)^{5}$ & $128(1)^{\prime}$ & $8(>32)^{5}$ & $256(1)^{\prime}$ & $8(8)^{5}$ & $256(1)^{\prime}$ & $128(2)^{5}$ & $16(16)^{5}$ & $64(4)^{5}$ & 63.63 \\
\hline \multirow[t]{3}{*}{ AMP } & 0 & 128 & 128 & $>256$ & $>256$ & $>256$ & $>256$ & $>256$ & $>256$ & $>256$ & $>256$ & $>256$ & na \\
\hline & $\mathrm{MIC} / 2$ & $128(1)^{\prime}$ & $128(1)^{\prime}$ & $>256$ & $>256$ & $>256$ & $>256$ & $>256$ & $>256$ & $>256$ & $>256$ & $>256$ & na \\
\hline & $\mathrm{MIC} / 5$ & $128(1)^{\prime}$ & $128(1)^{\prime}$ & $>256$ & $>256$ & $>256$ & $>256$ & $>256$ & $>256$ & $>256$ & $>256$ & $>256$ & na \\
\hline \multirow[t]{3}{*}{ FEP } & 0 & $>256$ & $>256$ & $>256$ & $>256$ & $>256$ & $>256$ & $>256$ & $>256$ & $>256$ & $>256$ & $>256$ & na \\
\hline & $\mathrm{MIC} / 2$ & $>256$ & $>256$ & $>256$ & $>256$ & $>256$ & $>256$ & $>256$ & $>256$ & $>256$ & $>256$ & $>256$ & na \\
\hline & $\mathrm{MIC} / 5$ & $>256$ & $>256$ & $>256$ & $>256$ & $>256$ & $>256$ & $>256$ & $>256$ & $>256$ & $>256$ & $>256$ & na \\
\hline \multirow[t]{3}{*}{ CLX } & 0 & $>256$ & $>256$ & $>256$ & $>256$ & $>256$ & $>256$ & $>256$ & $>256$ & $>256$ & $>256$ & $>256$ & na \\
\hline & $\mathrm{MIC} / 2$ & $>256$ & $16(>16)^{5}$ & $>256$ & $>256$ & $>256$ & $>256$ & $>256$ & $>256$ & $>256$ & $>256$ & $>256$ & 1.1 \\
\hline & $\mathrm{MIC} / 5$ & $>256$ & $32(>8)^{5}$ & $>256$ & $>256$ & $64(>4)^{5}$ & $>256$ & $>256$ & $>256$ & $>256$ & $>256$ & $>256$ & 18.2 \\
\hline
\end{tabular}

aAntibotics [TET : tetracycline, DOX: doxycyclin, CIP : ciprofloxacin, NOR : norfloxacin, STR : streptomycin, KAN : kanamycin, CHL: chloramphenicol, ERY : erythromycin, AMP : ampicillin, FEP: cefepime, CLX: cloxacillin].
bBacterial strains: Escherichia coli [AG100, AG100A, AG100Atet], Pseudomonas aeruginosa [PA124], Enterobacter aerogenes [CM64, EA3, EA27, EA289], Enterobacter cloacae [BM67], Klebsiella pneumoniae [KP55], Providencia 'Bacterial strains: Escherichia coli [AG100, AG100A, AG100Atet], Pseudomonas aeruginosa [PA124], Enterobacter aerogenes [CM64, EA3, EA27, EA289], Enterobacter cloacae [BM67], Klebsiella pneumoniae [KP55], ProviC
stuartii [NAE16]. 'PBSSS: percentage of bacteria strain on which synergism has been observed; (): fold increase in MIC values of the antibiotics after association with plants extract; S: Synergy, I: Indifference; na: not applicable. 
Table 5 MIC of different antibiotics after the association of the extract of Telfairia occidentalis at MIC/2, MIC/5 against eleven MDR bacteria

\begin{tabular}{|c|c|c|c|c|c|c|c|c|c|c|c|c|c|}
\hline \multirow[t]{2}{*}{ Antibiotics $^{\mathrm{a}}$} & \multicolumn{11}{|c|}{ Bacterial strains ${ }^{\mathrm{b}}, \mathrm{MIC}(\mu \mathrm{g} / \mathrm{mL})$ of antibiotics in the absence and presence of the extract } & \multirow[b]{2}{*}{ NEA16 } & \multirow{2}{*}{ PBSS $^{\mathrm{C}}(\%)$} \\
\hline & Extract concentration & PA124 & AG100 & AG102 & AG100Atet & CM64 & EA3 & EA27 & EA289 & BM67 & KP55 & & \\
\hline \multirow[t]{3}{*}{ TET } & 0 & 8 & 16 & 256 & 64 & 8 & 16 & 64 & 16 & 8 & $>256$ & 4 & \\
\hline & $\mathrm{MIC} / 2$ & $4(2)^{5}$ & $8(2)^{5}$ & $256(1)^{\prime}$ & $32(2)^{5}$ & $\leq 2(>4)^{5}$ & $\leq 2(>8)^{5}$ & $64(1)^{1}$ & $8(2)^{5}$ & $4(2)^{5}$ & $256(>1)^{s}$ & $\leq 2(>2)^{5}$ & 81.8 \\
\hline & $\mathrm{MIC} / 5$ & $4(2)^{5}$ & $8(2)^{5}$ & $256(1)^{\prime}$ & $32(2)^{5}$ & $\leq 2(>4)^{5}$ & $\leq 2(>8)^{5}$ & $64(1)^{1}$ & $8(2)^{5}$ & $4(2)^{5}$ & $256(>1)^{s}$ & $4(1)^{\prime}$ & 72.7 \\
\hline \multirow[t]{3}{*}{ DOX } & 0 & 16 & 8 & 32 & 32 & 32 & 32 & 32 & 32 & 8 & 32 & 64 & na \\
\hline & $\mathrm{MIC} / 2$ & $2(8)^{5}$ & $\leq 2(>4)^{5}$ & $16(2)^{5}$ & $4(8)^{5}$ & $4(8)^{5}$ & $\leq 2(>16)^{5}$ & $4(8)^{5}$ & $16(2)^{5}$ & $4(2)^{5}$ & $\leq 2(>16)^{5}$ & $32(2)^{5}$ & 100 \\
\hline & $\mathrm{MIC} / 5$ & $8(2)^{5}$ & $\leq 2(>4)^{5}$ & $32(1)^{\prime}$ & $8(4)^{5}$ & $\leq 2(>16)^{5}$ & $\leq 2(>16)^{5}$ & $8(4)^{5}$ & $16(2)^{5}$ & $\leq 2(>4)^{5}$ & $64(<0.5)$ & $64(1)^{\prime}$ & 72.7 \\
\hline \multirow[t]{3}{*}{$\mathrm{CIP}$} & 0 & 32 & 4 & 128 & 64 & 64 & 128 & $\leq 2$ & 8 & 128 & 64 & 128 & na \\
\hline & $\mathrm{MIC} / 2$ & $32(1)^{\prime}$ & $\leq 2(>2)^{5}$ & $64(2)^{5}$ & $\leq 2(>32)^{5}$ & $16(4)^{\mathrm{s}}$ & $\leq 2(>64)^{5}$ & $\leq 2$ & $\leq 2(>4)^{5}$ & $128(1)^{\prime}$ & $\leq 2(>32)^{5}$ & $128(1)^{\prime}$ & 70 \\
\hline & $\mathrm{MIC} / 5$ & $32(1)^{\prime}$ & $\leq 2(>2)^{5}$ & $64(2)^{5}$ & $\leq 2(>32)^{5}$ & $16(4)^{5}$ & $\leq 2(>64)^{5}$ & $\leq 2$ & $\leq 2(>4)^{5}$ & $128(1)^{1}$ & $\leq 2(>32)^{5}$ & $128(1)^{\prime}$ & 70 \\
\hline \multirow[t]{3}{*}{ NFX } & 0 & 128 & 128 & 64 & 128 & $\leq 2$ & 128 & 32 & 64 & 128 & 128 & 256 & na \\
\hline & $\mathrm{MIC} / 2$ & $64(2)^{s}$ & $4(32)^{5}$ & $32(2)^{5}$ & $4(32)^{5}$ & $\leq 2$ & $4(32)^{5}$ & $4(8)^{5}$ & $32(2)^{5}$ & $128(1)^{\prime}$ & $\leq 2(>64)^{5}$ & $128(2)^{5}$ & 90 \\
\hline & $\mathrm{MIC} / 5$ & $32(4)^{5}$ & $4(32)^{5}$ & $32(2)^{5}$ & $4(32)^{5}$ & $\leq 2$ & $4(32)^{5}$ & $4(8)^{5}$ & $16(4)^{5}$ & $128(1)^{\prime}$ & $8(16)^{5}$ & $256(1)^{\prime}$ & 80 \\
\hline \multirow[t]{3}{*}{ STR } & 0 & 256 & $\leq 2$ & 256 & 64 & 8 & 32 & 16 & 64 & $\leq 2$ & 4 & 64 & na \\
\hline & $\mathrm{MIC} / 2$ & $256(1)^{\prime}$ & $\leq 2$ & $256(1)^{1}$ & $16(4)^{\mathrm{s}}$ & $\leq 2(>4)^{5}$ & $\leq 2(>16)^{5}$ & $16(1)^{1}$ & $\leq 2(>32)^{5}$ & $\leq 2$ & $\leq 2(>2)^{5}$ & $16(4)^{5}$ & 66.7 \\
\hline & $\mathrm{MIC} / 5$ & $256(1)^{\prime}$ & $\leq 2$ & $256(1)^{1}$ & $8(8)^{5}$ & $\leq 2(>4)^{5}$ & $\leq 2(>16)^{5}$ & $16(1)^{\prime}$ & $\leq 2(>32)^{5}$ & $\leq 2$ & $\leq 2(>2)^{5}$ & $16(4)^{\mathrm{s}}$ & 66.7 \\
\hline \multirow[t]{3}{*}{ KAN } & 0 & ND & 8 & 128 & 32 & $\leq 2$ & 16 & 16 & 32 & $\leq 2$ & 8 & $\leq 2$ & na \\
\hline & $\mathrm{MIC} / 2$ & ND & $4(2)^{5}$ & $128(1)^{1}$ & $8(4)^{5}$ & $\leq 2$ & $\leq 2(>8)^{5}$ & $\leq 2(>8)^{5}$ & $\leq 2(>16)^{5}$ & $\leq 2$ & $8(1)^{1}$ & $\leq 2$ & 71.4 \\
\hline & $\mathrm{MIC} / 5$ & ND & $4(2)^{5}$ & $128(1)^{l}$ & $\leq 2(>16)^{5}$ & $\leq 2$ & $\leq 2(>8)^{5}$ & $\leq 2(>8)^{5}$ & $\leq 2(>16)^{5}$ & $\leq 2$ & $8(1)^{1}$ & $\leq 2$ & 71.4 \\
\hline \multirow[t]{3}{*}{$\mathrm{CHL}$} & 0 & 32 & 64 & $>256$ & 64 & 256 & 32 & $>256$ & 64 & 16 & 128 & 128 & na \\
\hline & $\mathrm{MIC} / 2$ & $16(2)^{\mathrm{s}}$ & $32(2)^{5}$ & $>256$ & $64(1)^{\prime}$ & $\leq 2(>128)^{5}$ & $4(8)^{5}$ & $256(>1)^{s}$ & $16(4)^{5}$ & $\leq 2(>8)^{5}$ & $16(8)^{5}$ & $16(8)^{5}$ & 90 \\
\hline & $\mathrm{MIC} / 5$ & $32(1)^{\prime}$ & $32(2)^{5}$ & $>256$ & $64(1)^{\prime}$ & $\leq 2(>128)^{5}$ & $8(4)^{5}$ & $256(>1)^{s}$ & $32(2)^{\mathrm{s}}$ & $16(1)^{\prime}$ & $64(2)^{5}$ & $64(2)^{5}$ & 70 \\
\hline \multirow[t]{3}{*}{ ERY } & 0 & 128 & 32 & 256 & 128 & $>256$ & 256 & 64 & 256 & 256 & 256 & 256 & na \\
\hline & $\mathrm{MIC} / 2$ & $64(2)^{5}$ & $16(2)^{5}$ & $>256$ & $32(4)^{5}$ & $\leq 2$ & $4(64)^{5}$ & $32(2)^{5}$ & $64(4)^{5}$ & $32(8)^{5}$ & $8(32)^{5}$ & $128(2)^{5}$ & 72.7 \\
\hline & $\mathrm{MIC} / 5$ & $64(2)^{\mathrm{s}}$ & $32(1)^{\prime}$ & $>256$ & $32(4)^{5}$ & $64(>4)^{5}$ & $4(64)^{5}$ & $64(1)^{\prime}$ & $256(1)^{\prime}$ & $32(8)^{5}$ & $16(16)^{5}$ & $128(2)^{5}$ & 45.5 \\
\hline \multirow[t]{3}{*}{ AMP } & 0 & 128 & 128 & $>256$ & $>256$ & $>256$ & $>256$ & $>256$ & $>256$ & $>256$ & $>256$ & $>256$ & na \\
\hline & $\mathrm{MIC} / 2$ & $256(0.5)^{\prime}$ & $128(1)^{\prime}$ & $>256$ & $>256$ & $>256$ & $256(>1)^{s}$ & $>256$ & $>256$ & $>256$ & $>256$ & $>256$ & na \\
\hline & $\mathrm{MIC} / 5$ & $256(0.5)^{\prime}$ & $128(1)^{1}$ & $>256$ & $>256$ & $>256$ & $>256$ & $>256$ & $>256$ & $>256$ & $>256$ & $>256$ & na \\
\hline \multirow[t]{3}{*}{ FEP } & 0 & $\mathrm{ND}$ & $>256$ & $>256$ & $>256$ & $>256$ & $>256$ & $>256$ & $>256$ & 256 & $>256$ & $>256$ & na \\
\hline & $\mathrm{MIC} / 2$ & ND & $>256$ & $>256$ & $>256$ & $>256$ & $>256$ & $>256$ & $>256$ & $>256(<1)$ & $8(>32)^{5}$ & $>256$ & 1.1 \\
\hline & $\mathrm{MIC} / 5$ & ND & $>256$ & $>256$ & $>256$ & $>256$ & $>256$ & $>256$ & $>256$ & $>256(<1)$ & $>256$ & $>256$ & na \\
\hline \multirow[t]{3}{*}{$C L X$} & 0 & $>256$ & 256 & $>256$ & $>256$ & $>256$ & $>256$ & $>256$ & $>256$ & $>256$ & $>256$ & $>256$ & na \\
\hline & $\mathrm{MIC} / 2$ & $>256$ & $64(>4)^{5}$ & $>256$ & $>256$ & $256(\geq 2)^{5}$ & $64(>4)^{5}$ & $>256$ & $>256$ & $>256$ & $>256$ & $>256$ & 27.3 \\
\hline & $\mathrm{MIC} / 5$ & $>256$ & $64(>4)^{5}$ & $>256$ & $>256$ & $256(\geq 2)^{s}$ & $128(>2)^{5}$ & $>256$ & $>256$ & $>256$ & $>256$ & $>256$ & 27.3 \\
\hline
\end{tabular}

${ }^{2}$ Antibotics [TET : tetracycline, DOX: doxycyclin, CIP: ciprofloxacin, NOR : norfloxacin, STR : streptomycin, KAN : kanamycin, CHL: chloramphenicol, ERY : erythromycin, AMP : ampicillin, FEP: cefepime, CLX: cloxacillin]. ${ }^{\mathrm{b} B a c t e r i a l}$ strains: Escherichia coli [AG100, AG100A, AG100Atet], Pseudomonas aeruginosa [PA124], Enterobacter aerogenes [CM64, EA3, EA27, EA289], Enterobacter cloacae [BM67], Klebsiella pneumoniae [KP55], Providencia

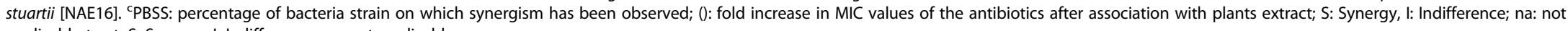
applicable tract; S: Synergy, I: Indifference; na: not applicable. 
improving the penetration of antibiotics in cells via membrane alteration [54]. However, further phytochemical investigations will be done to isolate the active constituents of $P$. nigrum, T. occidentalis and $V$. amygdalina. Besides, toxicological studies will be carried out to evaluate their safety.

\section{Conclusion}

The overall results of the present study provide baseline information for the possible use of the tested plants and mostly $P$. nigrum, T. occidentalis and $V$. amygdalina in the control of infections due to MDR Gram-negative bacteria. In addition, the extracts from $P$. nigrum and T. occidentalis could be used in association with antibiotics to combat multidrug resistant pathogens.

\section{Additional file}

Additional file 1: Table S1. Bacterial strains and features, Table S2. Effects of different concentrations of extracts on the MIC $(\mu \mathrm{g} / \mathrm{mL})$ of antibiotics against the PA124 strain. Table S3. FIC of different antibiotics after the association of the extracts of black Piper nigrum fruits and Telfairia occidentalis leaves at the concentrations MIC/2, MIC/5 against eleven actives efflux pumps MDR bacteria strains.

\section{Abbreviations}

AMP: Ampicillin; ATCC: American type culture collection; CEF: Cefepime; CFU: Colony forming unit; CHL: Chloramphenicol; CIP: Ciprofloxacin; DMSO: Dimethylsulfoxyde; EPI: Efflux pump inhibitor; ERY: Erythromycin; FIC: Fractional inhibitory concentration; INT: p-iodonitrotetrazolium chloride; KAN: Kanamycin; MDR: Multidrug resistant; MHB: Mueller hinton broth; MIC: Minimal inhibitory concentration; NOR: Norfloxacin; PABN: Phenylalanine arginine $\beta$-Naphthylamide; RND: Resistance nodulation-cell division; STR: Streptomycin; TET: Tetracycline.

\section{Competing interest}

The authors declare that there are no conflict of interest.

\section{Authors' contributions}

JAKN, MM and MS carried out the study; VK designed the experiments. JAKN MM, JPD and VK wrote the manuscript; VK, JRK and DC supervised the work; VK provided the bacterial strains; all authors read and approved the final manuscript.

\section{Acknowledgements}

Authors are thankful to Romanian Government and The Agence Universitaire de la Francophonie for travel grant to JAKN, and also to Professor Jean-Marie Pagès, Chair of the UMR-MD1 Unit, Université de la Mediterranée, France for providing us with some MDR bacteria. Authors are also thankful to Dr Gerald Ngo Teke for the language editing.

\section{Author details}

'Department of Biochemistry, Faculty of Science, University of Dschang, Dschang, Cameroon. ${ }^{2}$ Department of Biochemistry and Molecular Biology, Faculty of Biology, University ALI Cuza, lasi, Romania.

Received: 7 March 2013 Accepted: 24 July 2013

Published: 25 July 2013

\section{References}

1. Ahluwalia G, Sharma SK: Philanthropy and medical science: at last a new dawn for tuberculosis also! Indian J Chest Dis Allied Sci 2007, 49:71-73.

2. Adwan G, Abu-Shanab B, Adwan K: Antibacterial activities of some plant extracts alone and in combination with different antimicrobials against multidrug-resistant Pseudomonas aeruginosa strains. Asian Pac J Trop Med 2010, 3(4):266-269.

3. Poole K: Efflux-mediated antimicrobial resistance. J Antimicrob Chemother 2005, 56:20-51.

4. Ates DA, Erdogrul OT: Antimicrobial activity of various medicinal and commercial plants extracts. Turk J Biol 2003, 27:157-162.

5. Rahman S, Parvez AK, Islam R, Khan MH: Antibacterial activity of natural spices on multiple drug resistant Escherichia coli isolated from drinking water Bangladesh. Ann Clin Microbiol Antimicrob 2011, 10:10.

6. Newman DJ, Cragg GM: Natural products as sources of new drugs over the last 25 years. J Nat Prod 2007, 70(3):461-477.

7. Coutinho HDL, Siqueira-Júnior JG, JP: Additive effects of Hyptis martiusii Benth with aminoglycosides against Escherichia coli. Indian J Med Res 2010, 131:106-108.

8. Nisar A, Fazal H, Abbasi BH, Farooq S, Ali M, Khan MA: Biological role of Piper nigrum L. (Black pepper): a review. Asian Pac J Trop Biomed 2012, 2(3):S1945-S1953.

9. Menon AN, Padmakumari KP, Jayalekshmy A: Essential oil composition of four major cultivars of Black Pepper (Piper nigrum L) III. J Essent Oil Res 2003, 15(3):155-157.

10. Kang MJ, Cho JYS, Duk K, Kim BH, Lee J: Bioavailability enhancing activities of natural compounds from medicinal plants. J Med Plant Res 2009, 3(13):1204-1211.

11. Ee GCL, Lim CM, Rahmani M, Shaari K, Bong CFJ: Pellitorine, a potential Anti-cancer lead compound against HL60 and MCT-7 cell lines and microbial transformation of piperine from Piper nigrum. Molecules 2010, 15(4):2398-2404

12. Vijayakumar RS, Surya D, Nalini N: Antioxidant efficacy of black pepper (Piper nigrum L.) and piperine in rats with high fat diet induced oxidative stress. Redox Rep 2004, 9(2):105-110.

13. Neha JMR: Antioxidant activity of Trikatu megaExt. Inter J Res Pharm Biomed Sci 2011, 2(2):624-628.

14. Erturk $\mathrm{O}$ : Antibacterial and antifungal activity of ethanolic extracts from eleven spice plants. Biologia Bratis/ 2006, 61(3):275-278.

15. Li S, Wang C, Li W, Koike K, Nikaido T, Wang MW: Antidepressant-like effects of Piperine and its derivative, antiepilepsirine. J Asian Nat Prod Res 2007, 9:421-430

16. Umit AK, Akgun KO: Antifungal activity of aqueous extracts of spices against bean rust (Uromyces appendiculatus). Allelopathy J 2009, 24:0973-5046.

17. Parmar VS, Bracke ME, Philippe J, Wengel J, Jain SC, Olsen CE, Bisht KS, Sharma NK, Courtens A, Sharma SK, Vennekens K, Van Marck V, Singh SK, Kumar N, Kumar A, Malhotra S, Kumar R, Rajwanshi VK, Jain R, Mareel MM: Anti-invasive activity of alkaloids and polyphenolics in vitro. Bioorg Med Chem 1997, 5(8):1609-1619.

18. Kumar S, Singhal V, Roshan R, Sharma A, Rembhotkar GW, Ghosh B: Piperine inhibits TNF- $a$ induced adhesion of neutrophils to endothelial monolayer through suppression of NF-K and IkB kinase activation. Eur $\rfloor$ Pharmacol 2007, 575:177-186.

19. Pathak N, Khandelwal S: Cytoprotective and immunomodulating properties of piperine on murine splenocytes: an in vitro study. Eur J Pharmacol 2007, 576(1-3):160-170.

20. Sunila ES, Kuttan G: Immunomodulatory and antitumor activity of Piper longum Linn. and piperine. J Ethnopharmacol 2004, 90(2-3):339-346.

21. Upadhyay RK, Jaiswal G: Evaluation of biological activities of Piper nigrum oil against Tribolium castaneum. Bull Insectology 2007, 60:57-61.

22. Tajuddin Ahmad S, Latif A, Qasmi I: Effect of $50 \%$ ethanolic extract of Syzygium aromaticum (L.) Merr. \& Perry. (clove) on sexual behaviour of normal male rats. BMC Complement Altern Med 2004, 4(1):17.

23. Sharma A, Kumar M, Kaur S: Modulatory effects of Syzygium aromaticum (L.) Merr. \& Perry and Cinnamomum tamala Nees \& Ebrem. on toxicity induced by chromium trioxide. Phytopharmacology 2011, 1(4):71-81.

24. Moleyar V, Narasimham P: Antibacterial activity of essential oil components. Int J Food Microbiol 1992, 16(4):337-342.

25. Palombo E: Traditional medicinal plant extracts and natural products with activity against oral bacteria: potential application in the prevention and treatment of oral diseases. eCAM 2011, 2011:680354.

26. Pinto E, Vale-Silva L, Cavaleiro C, Salgueiro L: Antifungal activity of the clove essential oil from Syzygium aromaticum on Candida, Aspergillus and dermatophyte species. J Med Microbiol 2009, 58:1454-1462.

27. Wagner $H$, Jurcic $K$, Deininger $R$ : Über die spasmolytische Wirkung von Eugenolestern und -äthern. Planta Med 1979, 37(09):9,14. 
28. Banerjee S, Das S: Anticarcinogenic Effects of an aqueous infusion of cloves on skin carcinogenesis. Asia Pacific J Cancer Prev 2005, 6(3):304-308.

29. Fregni V, Casadio R: Kinetic characterization of the ATP-dependent proton pumps in bacterial photosynthetic membranes: a study with the fluorescent probe 9-amino-6-chloro-2-methoxyacridine. BBA Bioenergetics 1993, 1143(2):215-222.

30. Pandey A, Singh P: Antibacterial activity of Syzygium aromaticum (clove) with metal ion effect against food borne pathogens. Asia J Plant Sci 2011, 1(2):69-80.

31. Eseyin OA, Ebong P, Ekpo A, Igboasoiyi A, Oforah E: Hypoglycemic effect of the seed extract of Telfairia occidentalis in rat. Pakistan J Biol Sci 2007, 10(3):498-501.

32. Oboh G, Nwanna EE, Elusiyan CA: Antioxidant and antimicrobial properties of Telfairia occidentalis (Fluted pumpkin) leaf extracts. J Pharmacol Toxicol 2006, 1(2):167-175.

33. Kayode AAA, Kayode OT, Odetola AA: Telfairia occidentalis ameliorates oxidative brain damage in Malnorished rats. nt J Biol Sci 2010, 4(1):10-18.

34. Iwalokun BB, SB, Durojaiye OO: An Antimicrobial Evaluation of Vernonia amygdalina (Compositae) against Gram - positive and Gram-Negative bacteria from Lagos, Nigeria. W Afr J Pharmacol Drug Res 2003, 19:9-15.

35. Uzoigwe CA, OK: Antimicrobial activity of Vernonia amygdalina on selected urinary tract pathogens. Afr J Microbiol Res 2011, 5(12):1467-1472.

36. Akinpelu DA: Antimicrobial activity of Vernonia amygdalina leaves. Fitoterapia 1999, 70(4):432-434.

37. Nwanjo HU, Nwokoro EA: Antidiabetic and biochemical effects of aqueous extract of Vernonia amygdalina leaf in normoglycaemic and and diabetic rats. J Innov Life Sci 2004, 7:6-10.

38. Kupchan SM, Hemingway RJ, Karim A, Werner D: Tumor inhibitors. XLVII. Vernodalin and vernomygdin, two new cytotoxic sesquiterpene lactones from Vernonia amygdalina Del. J Organic Chem 1969, 34(12):3908-3911.

39. Izevbigie EB: Discovery of water soluble anticancer agents from a vegetable found in Benin City, Nigeria. Exp Biol Med 2003, 228:293-298.

40. Tadesse A, Gebre-Hiwot A, Asres K, Djote M, Frommel D: The in-vitro activity of Vernonia amygdalina on Leishmania acthiopica. Ethiop Med J 1993, 31:183-189.

41. Fasola TO, Okeocha PC, Odetola A: Screening for hypoglycaemic potential of Vernonia amygdalina. Ethnobotanical Leaflets 2010, 14:759-765.

42. Ibrahim TA, Ajala L, Adetuyi FO, Jude-Ojei B: Assessment of the antibacterial activity of Vernonia amygdalina and Occimum gratissimum leaves on selected food borne pathogens. Elec J Env Agricult Food Chem 2009, 8(11):1212-1218.

43. Nwanjo HU: Efficacy of aqueous leaf extract of Vernonia amygdalina on plasma lipoprotein and oxidative status in diabetic rat models. Niger $J$ Physiol Sci 2005, 20(1-2):39-42.

44. Harbone JB: Phytochemical methods: A guide to modern techniques of plant analysis. London: Chapman and Hall; 1973

45. Eloff JN: A sensitive and quick microplate method to determine the minimal inhibitory concentration of plant extracts for bacteria. Planta Med 1998, 64:711-713.

46. Mativandlela SPN, Lall N, Meyer JJM: Antibacterial, antifungal and antitubercular activity of Pelargonium reniforme (CURT) and Pelargonium sidoides (DC) (Geraniaceae) root extracts. S Afr J Bot 2006, 72:232-237.

47. Kuete V, Ngameni B, Simo CCF, Tankeu RK, Ngadjui BT, Meyer JJM, Lall N, Kuiate JR: Antimicrobial activity of the crude extracts and compounds from Ficus chlamydocarpa and Ficus cordata (Moraceae). J Ethnopharmacol 2008, 120(1):17-24.

48. Shahverdi AR, Monsef-Esfahani HR, Tavasoli F, Zaheri A, Mirjani R: TransCinnamaldehyde from Cinnamomum zeylanicum Bark Essential Oil Reduces the Clindamycin Resistance of Clostridium difficile in vitro. J Food Sci 2007, 72(1):S055-S058.

49. Braga LC, Leite AAM, Xavier KGS, Takahashi JA, Bemquerer MP, ChartoneSouza E, Nascimento AMA: Synergic interaction between pomegranate extract and antibiotics against Staphylococcus aureus. Can J Microbiol 2005, 51(7):541-547.

50. Cowan MM: Plant products as antimicrobial agents. Clin Microbiol Rev 1999, 12(4):564-582.

51. Kuete V: Potential of Cameroonian plants and derived products against microbial infections: a review. Planta Med 2010, 76(EFirst):1479-1491.

52. Karaman I, Şahin F, Güllüce $M$, Öğütçü $H$, Şengül $M$, Adıgüzel $A$ : Antimicrobial activity of aqueous and methanol extracts of Juniperus oxycedrus L. J Ethnopharmacol 2003, 85(2-3):231-235.
53. Ono T, Kashimura M, Suzuki K, Oyauchi R, Miyachi J, Ikuta $H$, Kawauchi $H$, Akashi T, Asaka T, Morimoto S: In vitro and in vivo antibacterial activities of the tricyclic ketolide te-802 and its analogues. J Antibiot (Tokyo) 2004, 57(8):518-527.

54. Pavithra VK, O Bhagya L: Antibacterial activity of black pepper (Piper nigrum Linn.) with special reference to its mode of action bacteria. Indian J Comp Microbiol Immunol Infect Dis 2009, 30(1):65-66.

55. Blot S, Depuydt P, Vandewoude K, De-Bacquer D: Measuring the impact of multidrug resistance in nosocomial infection. Curr Opin Infect Di 2007, 20:391-396.

56. Papadopoulos CJCC, Chang BJ: Role of the MexAB-OprM efflux pump of Pseudomonas aeruginosa in tolerance to tea tree (Melaleuca alternifolia) oil and its monoterpene components terpinen-4-ol, 1,8-cineole and aterpineol. Appl Environ Microbiol 2008, 74:1932-1935.

57. Lomovskaya O, Bostian KA: Practical applications and feasibility of efflux pump inhibitors in the clinic-a vision for applied use. Biochem Pharmacol 2006, 71:910-918.

58. Pages J-M, Lavigne J-P, Leflon-Guibout V, Marcon E, Bert F, Noussair L, Nicolas-Chanoine M-H: Efflux Pump, the Masked Side of ß-Lactam Resistance in Klebsiella pneumoniae clinical isolates. PLoS One 2009, 4(3):e4817.

59. Lorenzi V, Muselli A, Bernardini AF, Berti L, Pagès JM, Amaral L, Bolla JM: Geraniol restores antibiotic activities against multidrug-resistant isolate from Gram-negative species. Antimicrob Agents Chemother 2009, 53:2209-2211

\section{doi:10.1186/1472-6882-13-190}

Cite this article as: Noumedem et al:: In Vitro antibacterial and antibiotic-potentiation activities of four edible plants against multidrug-resistant gram-negative species. BMC Complementary and

Alternative Medicine 2013 13:190.

\section{Submit your next manuscript to BioMed Central and take full advantage of:}

- Convenient online submission

- Thorough peer review

- No space constraints or color figure charges

- Immediate publication on acceptance

- Inclusion in PubMed, CAS, Scopus and Google Scholar

- Research which is freely available for redistribution 